\title{
Glaucomas in Africans
}

\section{Ian Murdoch}

Institute of Ophthalmology, Bath Street, London EC1V 9EL11

\section{INTRODUCTION}

It is with great pleasure I accept the task to produce a series of thought windows on a subject that challenges me daily ... the glaucomas! I thought a series of short pieces might be more digestible, so if, for example, you feel frustrated that I have not amplified on disc diagnosis for the glaucomas or classification of the glaucomas, etc., then either drop me a note with suggestions or wait a little and the subject may crop up anyway in fullness of time.

\section{GLAUCOMAS}

Glaucomas are a group of diseases with a common endpoint, a characteristic optic neuropathy. This characteristic neuropathy is associated with loss of visual function most commonly assessed by visual field testing. The classification of this group of diseases remains incomplete. If the pressure is increased sufficiently in an eye for a long enough period then this results in the optic neuropathy of glaucoma. This happens in all secondary glaucomas. There was confusion some years ago in our understanding of the disease, since intraocular pressure was included in the definition of the disease. With the advent of population studies it became apparent that, in some populations, a significant proportion of those with the characteristic neuropathy and changes of visual function did not have intraocular pressures raised above the range for the normal population. In $1989 \mathrm{Al}$ Sommer wrote a short article which changed the way IOP is considered from definition to major risk factor for glaucomatous optic neuropathy. ${ }^{1}$

The definition of glaucomatous optic neuropathy remains a challenge with no clear descriptor ahead of any others. A proposal based on centiles of normal populations has been published for epidemiological studies (table 1). ${ }^{2} \mathrm{I}$ personally find George Spaeth's DDLS very helpful (figure $1)$.

Table 1. Foster et al scheme for diagnosis of glaucoma in cross sectional prevalence surveys (The diagnosis is made according to three levels of evidence) $)^{2}$

\begin{tabular}{|l|l|}
\hline $\begin{array}{l}\text { Category } 1 \text { diagnosis (structural } \\
\text { and functional evidence) }\end{array}$ & $\begin{array}{l}\text { Eyes with a CDR or CDR asymmetry }>97.5 \text { th percentile for the normal population, } \\
\text { or a neuroretinal rim width reduced to }<0.1 \text { CDR (between } 11 \text { to } 1 \mathrm{o}^{\prime} \text { clock or } 5 \text { to } 7 \\
\text { o'clock) that also showed a definite visual field defect consistent with glaucoma. }\end{array}$ \\
\hline $\begin{array}{l}\text { Category } 2 \text { diagnosis (advanced } \\
\text { structural damage with }\end{array}$ & $\begin{array}{l}\text { If the subject could not satisfactorily complete visual field testing but had a CDR or } \\
\text { CDR asymmetry }>99.5 \text { th percentile for the normal population, glaucoma was } \\
\text { diagnosed solely on the structural evidence. }\end{array}$ \\
$\begin{array}{l}\text { In diagnosing category } 1 \text { or } 2 \text { glaucoma, there should be no alternative explanation } \\
\text { for CDR findings (dysplastic disc or marked anisometropia) or the visual field } \\
\text { defect (retinal vascular disease, macular degeneration, or cerebrovascular disease). }\end{array}$ \\
\hline $\begin{array}{l}\text { Category } 3 \text { diagnosis (Optic disc } \\
\text { not seen. Field test impossible) }\end{array}$ & $\begin{array}{l}\text { If it is not possible to examine the optic disc, glaucoma is diagnosed if: } \\
\text { The visual acuity }<3 / 60 \text { and the IOP }>99.5 \text { th percentile, or } \\
\text { The visual acuity }<3 / 60 \text { and the eye shows evidence of glaucoma filtering } \\
\text { surgery, or medical records were available confirming glaucomatous visual } \\
\text { morbidity. }\end{array}$ \\
\hline
\end{tabular}

Correspondence: Ian Murdoch, Institute of Ophthalmology, Bath Street, London EC1V 9EL11 • e-mail: i.murdoch@ucl.ac.uk 
Please never loose sight of the fact that, with the exception of the rarer childhood glaucomas, age remains the most important risk factor for the glaucomas followed by IOP and then family history.

\section{Africans}

It is an undisputable fact that Africa has the most diverse phenotypic demonstration of the human form. This is no surprise since genetically we probably all derive from a single ancestor on the continent, hence the genetic pool has been creating variety for the longest period. ${ }^{4}$ Thus Fula, Masai, Zulu, Hausa, Ewe, Surma, Darod, etc can often be distinguished by their phenotype. As noted above, family history is the third most important risk factor for many glaucomas, implying a genetic element and indeed some genes are beginning to be linked to various forms of the glaucomas. ${ }^{5,6,7}$ It may be no surprise therefore if the pattern of glaucomas differs between different African populations... Africans.

\begin{tabular}{|c|c|c|c|c|c|c|c|}
\hline & \multicolumn{3}{|c|}{ Narrowest width of rim (rim/disc ratio) } & \multirow[b]{2}{*}{$\begin{array}{l}\text { DDLS } \\
\text { Stage }\end{array}$} & \multirow[b]{2}{*}{$\underset{\text { nerve }}{1.25 \mathrm{~mm} \text { optic }}$} & \multirow{2}{*}{$\frac{\text { Examples }}{1.75 \mathrm{~mm} \text { optic }}$} & \multirow[b]{2}{*}{$\begin{array}{l}2.25 \mathrm{~mm} \text { optic } \\
\text { nerve }\end{array}$} \\
\hline $\begin{array}{l}\text { DDLS } \\
\text { Stage }\end{array}$ & $\begin{array}{l}\text { For Small Disc } \\
<1.50 \mathrm{~mm}\end{array}$ & $\begin{array}{l}\text { For Average Size } \\
\text { Disc } 1.50-2.00 \mathrm{~mm}\end{array}$ & $\begin{array}{l}\text { For Large Disc } \\
>2.00 \mathrm{~mm}\end{array}$ & & & & \\
\hline Oa & .5 or more & .4 or more & .3 or more & $0 a$ & & & \\
\hline ob & .4 to .49 & .3 to .39 & .2 to .29 & $0 b$ & & & \\
\hline$\uparrow$ & .3 to .39 & .2 to .29 & $\therefore$ to 19 & 1 & & & \\
\hline 2 & .2 to .29 & .1 to .19 & less than .1 & 2 & & & \\
\hline 3 & .1 to .19 & less than .1 & 0 for less than $45^{\circ}$ & 3 & & & \\
\hline 4 & less than .1 & 0 for less than $45^{\circ}$ & 0 for $46^{\circ}$ to $90^{\circ}$ & 4 & & & \\
\hline 5 & 0 for less than $45^{\circ}$ & 0 for $46^{\circ}$ to $90^{\circ}$ & 0 for $91^{\circ}$ to $180^{\circ}$ & 5 & & & \\
\hline 6 & 0 for $46^{\circ}$ to $90^{\circ}$ & 0 for $91^{\circ}$ to $180^{\circ}$ & 0 for $181^{\circ}$ to $270^{\circ}$ & 6 & & & \\
\hline $7 a$ & 0 for $91^{\circ}$ to $180^{\circ}$ & 0 for $181^{\circ}$ to $270^{\circ}$ & $\begin{array}{l}0 \text { for more than } \\
270^{\circ}\end{array}$ & $7 a$ & & & \\
\hline $7 \mathrm{~b}$ & $\begin{array}{c}0 \text { for more than } \\
180^{\circ}\end{array}$ & $\begin{array}{l}0 \text { for more than } \\
270^{\circ}\end{array}$ & & $7 \mathrm{~b}$ & & & \\
\hline
\end{tabular}

Figure 1. Spaeth's Disc Damage Likelihood Scale (DDLS) nomogram. ${ }^{3}$

DDLS is based on the radial width of the neuroretinal rim measured at its thinnest point. Unit of measurement is $\mathrm{rim} /$ disc ratio (ie, the radial width of the rim compared to the diameter of the disc in the same axis). When there is no rim remaining, the rim/disc ratio is 0 . The circumferential extent of rim absence ( $0 \mathrm{rim} / \mathrm{disc}$ ratio) is measured in degrees. Caution must be taken to differentiate the actual absence of rim from sloping of the rim as, for example, can occur temporally in some patients with myopia. A sloping rim is not an absent rim. Because rim width is a function of disc size, disc size must be evaluated prior to attributing a DDLS stage. This is done with a $60 \mathrm{D}$ to $90 \mathrm{D}$ lens with appropriate corrective factors. The Volk $66 \mathrm{D}$ lens minimally underestimates the disc size. Corrective factors for other lenses are: Volk $60 \mathrm{D} \times .88,78 \mathrm{D} \times 1.2,90 \mathrm{D} \times 1.33$; Nikon $60 \mathrm{D} \times 1.03,90 \mathrm{D}$ $\times 1.63$.

Another aspect to this is the rich and diverse cultural approaches to health and therapy. A majority of glaucomas are asymptomatic until it is late in the disease process. Finding cases and giving preventive therapy is a challenge in any community. Acceptance of interventions will vary and the clinician must be prepared to approach and adapt the subject of case findings and therapy to the cultural setting of their local community.

\section{GLAUCOMAS IN AFRICANS}

For any ophthalmologist hoping to work on the challenge of glaucomas in their local community it is vital they appreciate the community in which they work will be unique. The demography, basic ocular parameters, disease patterns, acceptance of case findings, acceptance of therapy and many other factors will vary. They should modify their practice accordingly. 


\section{REFERENCES}

1. Sommer A. Intraocular pressure and glaucoma. Am J Ophthalmol 1989; 107(2):186-8.

2. Foster PJ, Buhrmann R, Quigley HA, Johnson GJ. The definition and classification of glaucoma in prevalence surveys. Br J Ophthalmol 2002; 86(2): 238-42.

3. Spaeth GL, Henderer J, Liu C, Kesen, M, Altangerel U, Bayer A, Katz LJ, Myers J, Rhee D, Steinmann W. The disc damage likelihood scale: reproducibility of a new method of estimating the amount of optic nerve damage caused by glaucoma. Trans Am Ophthalmol Soc 2002;100:181-186.

4. http://news.nationalgeographic.com/news/2001/01/0111 origins.html.

5. Gudmar Thorleifsson G, Magnusson KP, Sulem P, Walters GB, Gudbjartsson DF, Stefansson $H$, Jonsson $T$, Jonasdottir A, Jonasdottir A, Stefansdottir G, Masson G,
Hardarson GA, Petursson H, Arnarsson A, Motallebipour M, Wallerman O, Wadelius C, Gulcher JR, Thorsteinsdottir U, Kong A, Jonasson F, Stefansson K. Common sequence variants in the LOXL1 gene confer susceptibility to exfoliation glaucoma. Science 2007; 7 September: 1397-1400.

6. Edwin M. Stone EM Fingert JH, Alward WLM, Nguyen TD, Polansky JR, Sunden SLF,Nishimura D, Clark AF, Nystuen A, Nichols BE, Mackey DA, Ritch R, Kalenak JW, Craven ER, Sheffield VC. Identification of a gene that causes primary open angle glaucoma. Science 1997; 31 January: 668-670.

7. Nguyen TD, Chen P, Huang WD, Chen H, Johnson D, Polansky JR. Gene structure and properties of TIGR, an olfactomedin-related glycoprotein cloned from glucocorticoid-induced trabecular meshwork cells. J Biol Chem 1998; 273: 6341-6350. 